\title{
MX1 Gene
}

National Cancer Institute

\section{Source}

National Cancer Institute. MX1 Gene. NCI Thesaurus. Code C113309.

This gene plays a role in GTP hydrolysis, interferon signaling and apoptosis. 